\title{
資料
}

\section{WHO の瀬対策}

\author{
第 8 報 攋の Control（その 1 )
}

犀 $\underset{\text { (沖繩愛楽園園長) }}{\text { 一 夫 }}$

癩の Control に最近の医学の成果を導入して行うに は, その地域の実情, 公衆衛生活動の機構や機能状態, さらに疫学的状況を考虑に入れて, 弾力的, 実際的, ま た経済的に行うべきである。

癩の瞢延している多くの地域で, 現存する色々の困難 な問題を克服することが如何に六ケ敷しいかは百も承知 の上で, Dr. Bechelli(1963年, 1965年), や WHO LEC （1966年）は，次のように述べている。『何を優先的にや るかの順位を各地域の現状にそくして作つた実際計画の 中で, 何が可能で, 何が不可能であるかをよく見きわめ て実行にうつさねばならない。と，限られた予算をも つ国々，癩に㗢く医師の不足，また他に重大な公衆衛生 問題をかかえている国々では，最初に手をつけること は, 何を置いてもL 型の全部と, 他の伝染性 Case, I 群で Lepromin の陰性のものを優先的に 治療すべきで ある。

現実には，Lepromin 反応をやる余裕のない国が多い ので, その場合は I 群の全部は, 優先的に治療する側に 入れるのが賢明である。

同時に家庭内に伝染性瀨をもつ接触者の子供を管理下 に置くこと, また癩患者の変形の予防のために考慮する ことも必要である。

とに角, 伝染性 Case とその接触者, 特に子供等を集 中的に管理下に置くような方法や, 活動が計画されねば ならない。

これとは逆に癩の仕事に適当な予算処置がなされてい る国では，癩の仕事が公衆衛生活動の中にとり入れられ ているかはとも角としても, その国の全瀨患者を出来る だけ早く診断し, 治療下に置かれるようにされるべきで あり，また全 Contact を観察下に置く必要がある。身 障の予防, およびリハビリティションを考慮することも 大切であるが, 流行地域の住民について, 特に子供を規
則的に検診することも欠かせない。

8. 1. 癩の治療における優先度

若し全患者を治療出来ないのなら，開放性（伝染性） 癩を優先すべきである。然しその場合 $\mathrm{T}$ 型患者が治療の 場に出て来た場合は, 治療するのは勿論のことである。 ただ Field Work で一人の医師, 一人のボランティヤ 一等がT型の Case の治療のために，L型を管理するこ とが不十分になる程に身をしばられて㗢かねばならない と言うことは，政策的には不合理である。

\section{2. 接触者の観察における優先度}

攋の仕事がよく管理されていても, 接触者を規則的に 管理下で検診出来るのは, WHO の経験によると, 通 例としてせいぜい全体の $30 \%$ か $40 \%$ にすぎない。それ故 にL型および他の伝染性の接触者, 特に15歳以下の家庭 接触者が，優先的に検診されるべきであろう。

若し出来れば Lepromin Test を行らことをすすめた い。その成績を考虑すれば Contact の検診の量を70\% または $80 \%$ にぼることも出来る。すなわち Lepromin 陰性者に集中して行うことが出来るからである。優先度 から言えば非伝染性 Case の Contact は, 患者が登記 される時とかまたは, Contact が診察に来た時に検査を するぐらいにしてよい。

8. 3. 患者の follow-up の優先度

不規則治療をしている伝染性患者の follow-up がま ず優先される。攋の管理業務が良く組織運営されていて も, 在籍の $10 \%$ 以上の患者は, Control からはずれるの が通常である。この『Out of Control』と言うのは, 場 合によると,『Absentee』とか『Lost Sight of』または 他の言葉で呼ばれているが，それはとに角として，登録 患者が 2 年以上も Control からはなれている者を称し ている。

攋の管理業務の重点は全伝染攋を常に追跡して管理下 
に置くことで， L型が Control 下になかつたり，L型 の子供の Contact が Follow-up されずにいるような場 合に， $\mathrm{T}$ 型の追跡に時間をついやすことは全く無意味で これを省くべきである。これが Control の基本的な考 え方である。

\section{4. 攋 Control の医学的方法}

癩の Control は主として, 化学療法を活用すること にその基礎を置いて来た。Sulfone 剤の規則的な，長期 間の治療は, 癩の伝染性を低下させ，地域の癩の発生を 減少せしめ得る。癩の発生率を著明に低下させるため に, 最少限どのくらいの伝染麻を治療したらよいかは現 在まだ確実な Data はない。この目的のために長期間の 計画が立てられ，何処かの Field でこの実験が行なわ れる必要があ万う。この研究の結果をまつている間に, 暫定的な方針として，瀨発生率を低下させるために，推 定される伝染性の癩の $75 \%$ が規則的に治療されるべき で，そのことが癩の Control に優先すべきだ。癩に用 いる予算に制限があつたり，または他の公衆衛生行政に 重大な問題をかかえている国では，目的の達成のため に，一応 5 年間上記の計画が実行されるべきだろう。

癩の治療には, 特にL型について, ある限界があるこ とは最近知られて来た。それ故に一層早期治療と診断が 強調されねばならないしそれだけに, 癩の予防対策もま た，重要な問題である。すなわち BCG 接種や，治療薬 の内服による発病防止の試みは，現在盛んに行われてい て, 攋の Control にもら一つの有力な武器を与えてく れている。

\section{4. 1. Case-finding}

Case-finding の方法は, その地域の癩の流行度に関係 して，選ばれるべきで, Program の行われる前に，嬾 専門家, 統計学者, 疫学専門家が参加して, その地域の 癩の状況 (病型, 年龄, 性, 分布等); 疫学的な調查分析, さらには地理的, 気候風土，栄養状況の他に，社会的， 経済的, 公衆衛生の調査（特別な地方病, 環境衛生, 死 亡率, 一般伝染病の状況）が先行されねばならない。一 国にとつて癩蔓延がどの程度ならば，癩が重要な公衆衛 生の問題となるか，また瀨濃厚地とはどの程度の流行を 言らのであるかを決定することは簡単なことではない。 然し大体次の規準を考えてよいだろう。人口 1,000 人に 対して1またはそれ以上の場合, その地域では麻は重要 な公衆衛生の問題と見なされてよいし，若し有病率が人 口 1,000 人に対して10以上であるなら，癩は正にその地 域で濃厚流行地である。
然し癩がその国の公衆衛生の問題になる場合は国状に よつて見解はさまざまである。㿎の流行を云々する場合 L型の率が常に問題の焦点になるもので, アフリカ, ア ジア, 南米で, WHO の L.A.T. が調査した所による と, 多くの国で癩の実数は, 現在知られている数の少く とも平均 2 倍はあると見てよいと報告している。

a. Contact Tracing について

癞の流行度の低い地域では, Case-finding として,も つともこの方法は有効的，かつ経済的，実際的な方法 で, 伝染性 Case の家族接触者, 特に子供の検診でこれ らを paramedical worker や公衆衛生看護婦があらかじ め検査して pick up した case を医師が Confirm をす る形で行われる。日常公衆衛生活動業務の中にこの Program が Integrate されることが望ましく、このた めの公衆衛生看護婦の協力は注目すべきものがある。攋 の流行度が人口 1,000 人に 1 以上の処では，これらの方 法にさらに加えて, 学童検診, 徵兵検查の利用, 工場の 健康検診, その他特別なグループの検診を併用するとよ い。伝染性型の Contact は少くとも 5 年間は毎年続け て検診するのを原則とする。

b. Mass Survey（集団検診）

瀨の mass Survey はただ癩の濃厚地域だけに限られ る方法で, 実施にあたつては, 他の疾患の検診や Smallpox 等の Vaccination の program と一緒に行つて, 癩だけを目的に実施することはすすめられない。理由は 単独にすれば費用がかかる上に癩を特別に差別すること に関係するからで，実際には世界でもある限られた地方 (Africa)にしか行われていない。Africa でも癩の濃厚 地のポケット地域においてのみ行われている。また mass Survey は少くとも住民の $90 \%$ 以上の検診率がないと意 味がない。

c. Urban area（都市）における検診

都市地域での Case-finding は特に難しく, 主として Contact Tracing に基礎を置いて，学童検診（学校の年 次健康診断）とか住民のあるグループの結核等の検診が 保健所で行われる時に行うことが望ましい。Skin Clinic とか性病 clinic の協力も重要だし，一般開業医の協力 は見のがせない。(Note：実際新患の60\%近くは開業医 の公衆衛生活動の協力によつて見つけられているのが沖 醔の現状である。)

8. 4. 2. 治療の方法

8. 4. 2. 1. 外来 (在宅) 治療

癩の外来患者の治療は, 地域の一般公衆衛生行政をつ 
かさどる保健所が主導権をもつべきであるが，実際には 保健所が十分適応した活動が出来るまでは, mobile Units（移動治療班）が暫定的な㗢きをせねばならない だろう。外来治療は, 癩の伝染性を低下せしめるような 方法が好ましいわけだが，また出来るだけ経済的に行う ことも大切である。

療羔所に入所している患者の治療と言うものは，外来 患者のそれに比べると，費用の点でも，またあらゆる面 で，少くとも10倍以上もの出費がかかるとされている。

治療としては，DDS 内服がす寸められるが，特別な 場合には，持続性注射も好まれて使われ，特にこれは mobile Units で好んで用いられている。経口内服は農 繁期に，また雨期にすすめられる方法で，患者に投与さ れる量は，地域の状況にもよるが，時には 3 力月分を与 えることもある。然しこの場合は患者の協力を得ること が緊要である。

規則治療の確認については，尿中の DDS の排泄を簡 単に試べる方法が提案されている。これによつて患者が DDS を正しく内服しているか否かを check 出来るよ うになっている。

[note]: Ehrlich の Urobilinogen を検出するのに 用いる方法で，フィルターの paper を使用したり，尿 を Test paper に滴下したりするだけで, Sulfone 剤 および Sulfon amides によつて起る黄色の反応できめ られる。

尿中の Sulfone 剂の存在は, DDS $100 \mathrm{mg}$ を内服し て，60 90分で証明出来るし，長期間内服しているもの では，治療を中止しても，20３0日は反応を示す。ただ PAS や procain, その他の誘導体でも偽以反応を示す ことがある。この他に Dr. Inalio Castro その他によつ て1963年に発表された, Aromatic Amines で paradimethyl aminobenzaldehyde の反応を利用したものもあ る。

1958年 Tokyo の WHO Inter-Regional Leprosy Conference で，規則治療に関する定義が下された。そ れによると処方量の少くとも $75 \%$ を飲んでいるものを規 定した。一体外来治療にとつて，最大の問題は，規則治 療を確認することである。不規則治療は患者が自分の健 康に対する無関心さと治療に対する熱意の不足に関係す るが，一方病気に対する無知，治療への無関心のために 患者は治療を勝手に中断しやすい。この問題を解決する 唯一の方法は患者教育であろら。各地域每に，規則的治 療が行われやすいように，状況に適した方法を研究する
必要がある。地域の公衆衛生活動, 道路の状況, 農繁期, 雨期を考慮するとか，また患者側の状態としては，足の 変形, 潰瘍, 治療所に歩いて通う距離交通費なども考え てやらねばいけない。治療所，移動班，治療支所（公 衆衛生機関を利用することが 望ましい。）を作つてやつ て，患者の家と治療の場との距離を最少限に短くするた めには，徒歩で $5 \mathrm{~km}$ を起えないようにするのがよい。 治療のために Center に出て来れない患者のためには十 分な機動性を発揮することも，癩の治療にたずさわる人 々の配慮と言うものである。

不規則治療の原因について調查を十分にして，治療へ の出席率を改善するための別の配虑として，ある国で は，地域単位で DDS を毎月または $2 \sim 3$ 力月置きに， 配つてあるくことを検討していて，南米の一部ではすで に実施している。

Field で癩による変形，奇型の予防を治療対策と共に 強力におしす寸め, 患者の手, 足, 眼の保護について, 系統立つた教育を行い，実際的には理学療法上から，足 を保護するための靴，手を保護するための装具を与える ことも必要である。

また移動治療班は，患者の癩以外の疾患にも簡単な治 療の出来るよらな機能が伴うとよい。またこのためには 公衆衛生機関とも協力することも一つの方法である。癩 患者の治療に 関して，個人開業医の協力は大切な問題 で，その他学校の教師や，地方政府の役人と言つた責任 ある人々とも管理についての協力を依頼することも大切 である。

\section{4. 2. 2. 入院患者治療}

癩療養所は急性の Reaction とか, 他の合併症の治 療, 成形外科, 理学療法, リハビリティション, 癩の研 究, 癩に働く者の訓練のために利用され，療養所を現在 もつている国々では，伝染性の強いCase を強制でなし に, 自由意志で一時的に入所せしめて,伝染性が低下した り，臨床的に病勢が軽快した時点で退所出来るようにせ 㸚ばならない。然しこの場合,全く細菌学的に陰性になる まで退所をまつ必要はない。1963年第 8 回国際攋学会で は，『患者を療羲所に 入所せしめるために癞の予算を枯 渇させたり，またそのために癩の Control の中核である 外来治療活動を低下させてはならない』と述べている。

急性の合併症や，治療経過中に起る他の疾患のために 一時入院が必要な患者や，形成外科の 適応をもつ患者 は，一般病院に入院して治療や，手術を受ければよい。 療養所から退所する患者は一般社会の中に帰るのであ 
つて, 決して特別な『部落』と名ずくる Negative Colony に癩患者だけを集中的に集めるようなことをして はならない。

8. 4. 3. 癩の Contact を発病から守るためには

癩の Control を公衆衛生活動の中に 組入れて行くこ とは，一般に各国で受け入れられて来た。治療の進歩を 考慮し，また子供や母親の心理的影響を考えると，子供
を伝染性の親から隔離することは，特別の Case に限る べきで，若し隔離が必要なら，子供を親戚の家に送る か，または子供をあずかる一般の施設に，一般の子供と 一緒に入れ親から守るべきである。

近年 BCG 接種や治療薬内服による発病予防の効果が 討議され，またすでに実施され，Contact に対する対策 も変化しつつある。

\title{
WHO の瀬対策
}

\author{
第 8 報 瀨の Control（その 2 )
}

犀川一夫

（沖繩愛楽園園長）

8. 4. 4. Rehabilitation (以下 Reh. と略す)

8. 4. 4. 1. Reh. の定義

Reh. とは身体的, 精神的に病気の負いめから完全に 回復することで, 治療により治癒した患者が平常の社会 生活にもどり, 以前の家庭, 社会, 職業に復帰すること を意味している。この考えを癩患者に適用するために第 一に必要なことは，身体的な欠陥を治療すると共に，患 者を含めて，家族，公衆をこの目的のために教育するこ とも一緒に考えて行かねばならない。彼等が正常なもと の場に復帰するだけでなく，社会が彼等を積極的に受け 入れ，Reh. の完成に協力と援助を与えねばならない。

WHO LEC は『Reh. とは身障者のための収容所, 養 育所を作ることではない。』と強調している。実はさう することとは全く反対なのである。㓜論現在多くの患者 は癩院に入所していて，そこを彼等の一生の住いの場と して生きており，また色々の理由から一一例えば盲人で あつたり，家族や親戚がなくて帰る家もなかつたり，社 会に偏見があつて帰る所のないこと一一癩院を生涯の安 住の地とせざるを得ない事実は百も承知していながら も, 敢て LEC はこの主張をくつがえそうとはしない。 社会復帰とは，患者だけを一つの場所に特別に集めるの ではなくて，一般社会にむしろ散らすことがその目的で あるからである。

8. 4. 4. 2. Reh. program の進め方

LEC は次のことを強調している。『Reh. の Program は患者の治療をしているその場所で準備が開始される心゙ きで，特に Reh. Center というような施設に患者を集
め, 住み込まサて行うようなものでなく, 働く人の訓練 の場であり, 教育, 示範の場でもある。入所患者の社会 に対する心理的な対応性は治療の開始と同時に準備され るべきものである。患者が家庭や社会に復帰出来るよう にすることは, 瀨の保健, 衛生教育の面でも重要な program の一つであり，Case Worker 等が患者に代つ て準備しなければならないだろう。』。

8. 4. 4. 3. 問題の発展

癩患者の $25 \%$ は何らかの形で，身体的に欠かんをもつ ていると推定されていることからして, 患者の多くは身 体的な Reh.の program が必要である。これと同時に 㓜論, 社会, 経済, 心理学的な program も必要だが, これは何も身体的欠かんを有する者だけでなく患者一般 を対象にすべきだろう。身体的な欠損は，形成外科，理 学療法で矯正出来るようになつた。

癩患者身障度は国々によつてその様相が異つているの で, 国際的に一定の分類の規準をきめて, 各国ごとに奇 型を分析し，調查しなければならない。この分析は病型 と奇型度, 性別, 年齢別との関係とか, どんな奇型が患 者の職業に障害になつたり, 生活上の不便を与えている かを解明するのに役立つ。

8. 4. 4. 4. program の内容

$\mathrm{a}$, 早期発見, 治療と変形予防対策

b，患者および雇用者の教育，啓蒙

c, 奇型の治療 (手術, 理学療法)

$\mathrm{d}$, 奇型修復の手術前後の理学療法は特に外科医と連 絡をして行うこと。 